Open Access

\title{
Examining start-up Intention of Indians through cognitive approach: a study using GEM data
}

\author{
Mohd Yasir Arafat ${ }^{1 *}$ and Imran Saleem ${ }^{2}$
}

\author{
* Correspondence: \\ myarafat.rs@amu.ac.in \\ ${ }^{1}$ Department of Commerce, Aligarh \\ Muslim University, Aligarh, India \\ Full list of author information is \\ available at the end of the article
}

\begin{abstract}
In this paper, the authors have investigated the factors that affect the decision to start a new business among Indians, using a sample of 2700 interviews of Global Entrepreneurship Monitor 2012 Adult Population Survey Data. Demographic and perceptual factors have been used as independent variables and Intentional Entrepreneur has been used as the dependent variable. Logistic Regression Model has been employed to measure the influence of independent variables on the dependent variables. Findings show that gender, perceived opportunities, selfefficacy (confidence in one's own ability, knowledge and skills), and risk perception are the major determining factors of new business start up in India. Policy implications of the findings have been discussed.
\end{abstract}

Keywords: Start-up, Entrepreneurship, Entrepreneurial intention, Self-efficacy, Fear of failure, India

\section{Background}

Many entrepreneurship researchers have established that entrepreneurship contributes to the economic growth and development (Ács, Szerb, \& Autio, 2011, Arenius \& Minniti, 2005; Bosma, 2013; Frederick \& Monsen, 2011, Lerner, 2010a, 2010b; Wennekers, Van Wennekers, Thurik, \& Reynolds, 2005; Wennekers \& Thurik, 1999). Governments all over the world are looking at entrepreneurship as a way to increasing the wealth and well being (Langowitz \& Minniti, 2007). Scholars have expressed confidence that it also enhances employment creation, productivity, growth, and innovation (Van Praag \& Versloot, 2007).

If entrepreneurship contributes to the growth and development, it is particularly important that we should understand what factors foster or discourage individuals from creating new businesses. Without understanding these factors, policies cannot be formulated and implemented effectively. Nowadays, cognitive approach has gained much attention in the attempt to explain entrepreneurship (Baron, 2004; Ahmad, Xavier and Bakar, 2014) at the individual level (Liñán \& Chen, 2009) and at the aggregate level (Linan, Santos and Fernández, 2011).

Entrepreneurs are influenced by the external environment through their motivations and perceptions, generating attitudes and intentions, which, in turn, determine behavior. A better understanding of thecontribution of perception to individuals new venture

(c) The Author(s). 2017 Open Access This article is distributed under the terms of the Creative Commons Attribution 4.0 International License (http://creativecommons.org/licenses/by/4.0/), which permits unrestricted use, distribution, and reproduction in any medium, provided you give appropriate credit to the original author(s) and the source, provide a link to the Creative Commons license, and indicate if changes were made. 
creation decision making will allow a design of more satisfactory programs aimed at increasing venture creation propensity among individuals (Langowitz \& Minniti, 2007).

Until now, a significant number of studies have been conducted, to measure the influence of some cognitive perceptions on the propensity of individuals to create a new venture, under the entrepreneurship literature, but the findings are inconsistent (Kim, 2008). Small size of convenient sample made up of university and school students is much prevailing in the existing literature (Lortie \& Castogiovanni, 2015). The GEM data has the advantage to overcome the above mentioned limitation. Most of the researches using GEM data have been conducted at global level and the results found were significant. Linan et al. (2011) have urged researchers to confirm these results at national level. In general, very few entrepreneurship studies have covered the developing countries in their analysis. This study uses a novel perspective of cognitive model to analyze the factors affecting the formation of intention to start a new business using 2012 GEM APS data of India. To our knowledge, this would be the first study to use this data to explain the start up propensity of Indians. We expect that this would be a great contribution. This studyis relevant as it enhances our understanding about entrepreneurial process in this developing country.

In this paper, we use individual level Adult Population Survey (APS) data collected in 2012 for the Global Entrepreneurship Monitor (GEM) Project. The data consists of a stratified representative sample of at least 2000 individuals per country in 69 economies. Our dependent variables, consider whether individuals are involved in starting a new business and the reasons why they chose to do so. Our independent variables include 'demographic characteristics' and perceptual variables. Using logistic regression models, we test for the relative importance of these variables on Indians' decision to start new businesses. Although studies focused on Indians' entrepreneurial behavior already exist, because of the size and scope of our sample, our work adds new breadth to the important research question - why individuals choose to start new businesses. More importantly, most existing studies use data on established businesses. As a result, they are affected by survival bias. Our data, instead, are remarkably well suited for the study of entrepreneurial propensity since they are collected at the time the respondent is in the process of starting a business. They are, therefore, free from both survival and hindsight biases.

\section{Theoretical framework and hypotheses}

According to cognitive approach, every human activity is influenced by mental processes, such as motivation, perceptions or attitudes (Krueger, 2003). People use these processes in acquiring information, performing different tasks, such as decision making and problem solving. In the words of Mitchell et al., (2002) , p. 97, "entrepreneurial cognitions are the knowledge structures that people use to make assessment, judgement or decisions involving opportunity evaluation, venture creation, and growth".

Under the entrepreneurial cognition approach different perceptual factors such as Bandura's $(1977,1982)$ perceived self-efficacy and Shapero's (1975) perceived desirability have been used to study start-up. These perceptions are helpful in explaining why entrepreneurs start new businesses. Perceptions are cognitive construct, represent external environment captured through the senses and consciousness, and elaborated 
in mind. These representations may differ because of cognitive biases. Cognitive biases are the tendency to make errors in judgement when facing complex problems with incomplete information. Entrepreneurs face high uncertainty and time pressure due to their working conditions, therefore, have a high propensity to several cognitive biases. These cognitive biases affect their level of perception. In this sense, compared to other people, they can perceive lower risk levels or higher confidence in their own capacities to start businesses.

\section{Opportunity perception}

Research on entrepreneurial opportunity has grown since the publishing of the seminal work by Shane and Venkataraman (2000) 15 years ago. Opportunity perception is a central motivating factor that encourages individuals to start their own businesses (Shane, Locke, \& Collins, 2003; McMullen and Shphered, 2006).

According to the theory of planned behavior, the behavior of individuals is influenced by their attitude(Ajzen, 1991). Ajzen has defined attitude as "the degree to which a person has a favorable or unfavorable evaluation or appraisal of the behavior in question" (p.188). When individuals perceive that there are many business opportunities, they evaluate their ability to trap the opportunities. If the individuals evaluate it positively, they will formulate a favorable attitude towards the behavior (Ajzen). This favorable attitude will lead to the formation of intention and behavior as well. In the same token, we argue that the perception of lucrative entrepreneurial opportunities will lead to entrepreneurial intention. Previous studies (Arafat and Saleem, 2017; Honjo, 2015) have also found support for this argument.Thus, we formulate the following hypothesis:

Hypothesis 1: The perception of opportunities has a positive influence on entrepreneurial intention.

\section{Fear of failure}

Researcher defined fear of failure as a negative emotion (Li, 2011; Patzelt and Shepherd, 2011; Welpe et al., 2012) which discourages from starting a business (Ekore and Okekeocha, 2012). According to the theory of appraisal of emotions, emotions are adaptive responses that reflect appraisals of specific events in the external environment, significant for individual's well being. In this respect, the experience of emotions involves affect and perceptions of meanings bound together in a moment. Thus, producing an intentional state where the effect is experienced as having been caused by some situation. As such, the emotional experience emerges from a process of appraisal and is associated with psychological and behavioral reactions.

According to this perspective, the experience of fear of failure as a temporary emotional state decreases an individual's propensity to start a venture. Li (2011) suggests that fear of failure is a feeling about the outcomes of a new venture, which affects people's judgment of the value and probability of founding a new venture. Caccoiti and Hayton (2015) have also concluded that fear of failure is a barrier to entrepreneurship and inhibit entrepreneurial behavior. We, therefore, proposed the following hypothesis:

Hypothesis 2: The fear of failure has a negative influence on entrepreneurial intention. 


\section{Self-efficacy}

The concept of self-efficacy was introduced by Bandura (1977). It is widely used in entrepreneurial cognitive research. Self-efficacy has been defined as the confidence in one's own capabilities to perform an action required to deal with prospective situations (Bandura 1982). In the words of Ajzen (1991), people's behavior is strongly influenced by the confidence in their skills and ability to perform the behavior in question. Self-efficacy belief can also influence the choice of activities, preparation for an activity, efforts expanded during the performance, as well as thought patterns and emotional reactions. According to Shapero and Sokol (1982), the decision to start a business depends on the perceived desirability and feasibility of entrepreneurial activity. This perception of feasibility refers to the confidence in one's own skills, knowledge and the ability to perform the entrepreneurial behavior or in other words self-efficacy. Krueger and Carsrud (1993) developed a model of Entrepreneurial Intention based on the theory of planned behavior. According to them entrepreneurial intention is influenced by perceived behavioral control or self-efficacy. Thus, the following hypothesis is proposed:

Hypothesis 3: Self-efficacy (confidence in one's skills) has a positive influence on entrepreneurial intention.

\section{Methods}

As we mentioned in the introductory section, statistical analysis is carried out using Global Entrepreneurship Monitor data (GEM). The main focus of thisstudy is to examine the cognitive aspects of Indian entrepreneurs. The Global Entrepreneurship Monitor is the world's foremost study of entrepreneurship. The questionnaire used by GEM, in data collection, includes some items which also measure the entrepreneurial cognition that may allow the analysis of the entrepreneurial intention of the respondents. Hence, the data collected by GEM have the advantage to overcome from some of the limitations of previous works.

As GEM questionnaire does not include all the items germane to entrepreneurial intention and perceptions, therefore, it is not possible to examine all the perceptual variables tested by previous studies. Nevertheless, We can examine some of them. The 2012 Adult Population Survey (APS) Data was downloaded from the GEM webpage (http://gemconsortium.org/data/sets). This data set includes a total of 198,391 observations for all the countries. The data were extracted by filtering and a sample of 2700 adults (18-64 years) was found. Data collection procedure of GEM has been discussed by Reynolds et al. (2005). Moreover, the survey provides data on 343 variables, we selected those variables which are coherent to the objectives of this study.

\section{Measures}

I. Dependent variable

1. Intentional entrepreneur (futsup): Individuals aged 18-64 planning to create a new venture in the next three years. This dichotomous variable was measured by taking 
value 1 if the respondent reply affirmatively to the question, "Are you, alone or with others, expecting to start a new business, including any type of self-employment, within the next three years?", and 0 otherwise.

II. Independent variables

\section{Perceptual Variables:}

a. Perception of Opportunity (opport): this binary variable takes the value 1 if the respondent's reply is yes to the question, "In the next six months there will be good opportunities to start up new businesses in the area where you live", and 0 if no.

b. Fear of failure or risk perception (fearfail): this binary variable takes the value 1 if the respondent's reply is yes to the question, "Fear of failure would be a brake for you if you had to launch business", and 0 if no.

c. Self-efficacy or Confidence in one's skills (suskill): this binary variable takes the value 1 if the respondent's reply is yes to the question, "You have the necessary knowledge, skills, and experience to start up a new business", and 0 if no.

2. Control Variables: demographic and economic variables.

a. Age: respondents were asked to provide their year of birth.

b. Gender: this binary variable takes value 0 for males and 1 for females.

c. Annual household income (GEMHHINC): the response categories were "Lowest 33 percentile", "Middle 33 percentile" and "Upper 33 percentile". Upper 33 percentile was taken as the reference category.

d. Work status (GEMWORK): apart from various categories "full time working" people wereincluded in the analysis as the reference category.

e. Education level (GEMEDUC): the responses have been harmonized for all the countries participating in GEM into five categories, "none", some secondary", "secondary degree", "post-secondary", and university bachelor's degree or higher".None or no education was taken as the reference category.

\section{Proposed regression model}

The model of logit regression has been used to estimate the probability that whether an individual belongs to a certain group (dependent $=1$ ), or not (independent $=0$ ). This model is also helpful in identifying the variable which explains the difference between both the groups. In addition, the logit model does not consider the distribution of data (Greene, 2002). For this study, therefore, we are using logit model because of two reasons:

1- The dependent variable (Intentional entrepreneur) is dichotomous.

2- All the independent variables are also dichotomous or categorical.

\section{Results and Discussion}

Descriptive statistics shows that 51.67 and 48.33 of the respondents were male and female respectively, with a number representative of different age groups. Table 1 shows only $14 \%$ individuals have intention to start their own business, $24 \%$ saw good opportunities in the area where they live, $28 \%$ feel that fear of failure would be a brake if they 
Table 1 Descriptive statistics

\begin{tabular}{llll}
\hline & Number & Mean & Std. Deviation \\
\hline Intentional Entrepreneur & 2680 & .14 & .344 \\
Age & 2700 & 33.70 & 11.363 \\
Gender & 2700 & - & - \\
Household Income & 2641 & $24,195.34$ & $31,708.319$ \\
Work status & 2591 & - & - \\
Educational level & 2677 & - & - \\
Opportunity perception & 2650 & .24 & .427 \\
Fear of failure & 2679 & .28 & .450 \\
Self-efficacy & 2687 & .40 & .489 \\
\hline
\end{tabular}

start a business, and $40 \%$ individuals perceive that they have the knowledge and skills required to start a new business.

Table 2 shows the correlation among the variables analyzed. It could be viewed that, the correlation among the variables are not so high, indicating multicollinearity is not a problem. Four of the eight variables have significant correlation with the intention to start a new business. Table shows that age, household income, educational level and fear of failure are not significantly correlated with the propensity to create new ventures. Male respondents are shown to be more likely to start their own business than female respondents $(r=-.155)$. In addition, respondents who are working full time are less likely to start their own businesses $(r=-.117)$. As expected, opportunity perception $(r=.164)$ and self-efficacy or confidence in one's skills $(r=.187)$ are positively related to intention to start new businesses. Table 3 shows summary of missing cases. Some $9.5 \%$ of the total cases analysed are missing.

Table 4 showed that Omnibus test is significant, denoting acceptance of hypothesis that $\beta$ coefficient are different from non-zero. This test gives an overall indication that the model is performing well.

Table 5 depicts the results of logistic regression for the complete sample of dependent and independent variables.Among the demographic factors, age shows a positive, but insignificant influence onstart up propensity. This suggests that intention to create firm is not associated with age, which is not consistent with the results of other studies examining this relationship (Fernandez et al. 2009; Linan et al. 2011; Ramos-Rodríguez et al. 2012; Tsai, Chang, \& Peng, 2016). The regression coefficient of gender shows a negative sign (-0.549), indicating the probability to start up is greater for men. This result is in congruence with the findings of the previous studies (Arenius \& Minniti, 2005; Linan et al. 2011; Noguera et al. 2013; Tsai et al. 2016).

All categories of work status exceptretired, show a significant relation with start-up intention. Homemaker and student have a negative impact on entrepreneurial intention. The odds ratio for both the categories indicate homemaker and student are half as likely to be entrepreneur as those working full time. Entrepreneurial intention of part time working people is two times more than those working full time. The odds ratio (2.6) for not working individuals, indicates that not working individuals 2.6 times more likely to start their own business than those who are working full time.

In the current model, educational level does not show a clear statistically significant relationship with entrepreneurial intention. All categories give a non significant value 


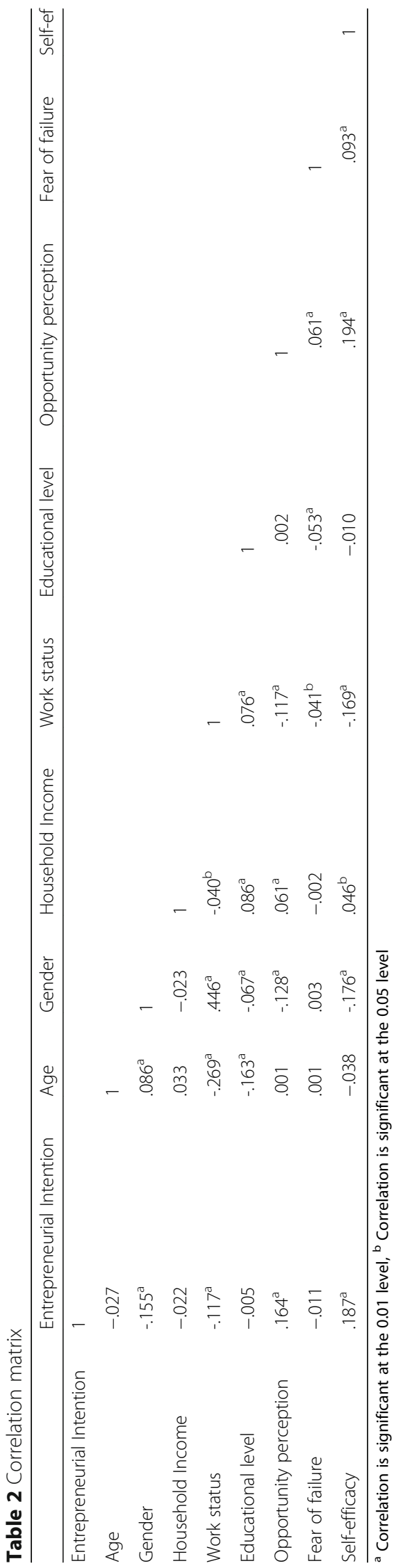


Table 3 Case processing summary

\begin{tabular}{llll}
\hline Unweighted cases & & Number & Percent \\
\hline & Included in Analysis & 2444 & 90.5 \\
Selected Cases & Missing Cases & 256 & \\
& Total & 2700 & 100.0 \\
Unselected Cases & & 0 & 0 \\
Total & & 2700 & 100.0 \\
\hline
\end{tabular}

when compared with the reference category (none or no education). This finding indicates that education does not affect the decision to start new business.

In the theory section, three hypotheses have been formulated germane to the impact of perceptual factors on the entrepreneurial intention of the adult population of India. Hypotheses 1 and 3 proposed that perception of entrepreneurial opportunity and selfefficacy have a positive influence on the intention to start a new business respectively. In contrast, hypothesis 2 considers that perception of risk or fear of failure has a negative effect on start-up propensity of Indians.

Since the results have been obtained in the expected direction; therefore, all the hypotheses are accepted. The odds ratio for opportunity perception is 2.001. This suggests that those who perceive entrepreneurial opportunities are two times more likely to become entrepreneur those who don't perceive opportunities. This finding corroborates with the similar studies examining this relation for different settings using specific country data (Ahmad et al., 2014; Noguera et al. 2013; Tsai et al. 2016) and aggregate data of various countries (Arenius, and Minniti 2005; Fernandaz et al., 2009; Langowitz and Minnit 2007; Linan et al. 2011; Ramos-Rodriguez, 2012). However, fear of failure has a negative influence on intention to start a business. The odds ratio for this variable indicates that individuals who perceive risk are less likely to start their own business. This result coincides with the results of earlier research (Arenius and Minniti, 2005; Fernandaz et al., 2009; Noguera 2013; Ramoz-Rodriguez, 2012). The third perceptual variable confidence in one's skill and ability to create new venture has a positive and significant influence on entrepreneurial intention. The odds ratio for this variable indicates that people who are confident in their skills and ability, their propensity to become an entrepreneur is 2.123 times higher than the rest of the population. This result is consistent with the findings of previous studies (e.g. Arenius and Minniti 2005; Langowitz and Minniti 2007; Noguera 2013; Tsai et al. 2016).

\section{Conclusions}

Entrepreneurship research is young, emerging (Ramos-Rodriguez et al., 2012), and a promising field for researchers (Shane \& Venkataraman, 2000). This is particularly true

Table 4 Omnibus test of model coefficient

\begin{tabular}{lllll}
\hline & & Chi-square & Df & Sig. \\
\hline Step 1 & Step & 206.990 & 16 & .000 \\
& Block & 206.990 & 16 & .000 \\
& Model & 206.990 & 16 & .000 \\
\hline
\end{tabular}


Table $\mathbf{5}$ Result of logistic regression

\begin{tabular}{|c|c|c|c|c|c|c|}
\hline & B & S.E. & Wald & $\mathrm{df}$ & Sig. & $\operatorname{Exp}(B)$ \\
\hline \multicolumn{7}{|l|}{ Demographic factors } \\
\hline Age & -.009 & .007 & 1.974 & 1 & .160 & .991 \\
\hline Gender & -.529 & .191 & 7.719 & 1 & .005 & .589 \\
\hline Household Income & & & 2.300 & 2 & .317 & \\
\hline -Lower 33 percentile & .146 & .147 & .988 & 1 & .320 & 1.158 \\
\hline -Middle 33 percentile & .242 & .162 & 2.234 & 1 & .135 & 1.273 \\
\hline Work status & & & 38.226 & 5 & .000 & \\
\hline -Part time & .589 & .274 & 4.640 & 1 & .031 & 1.803 \\
\hline -Retired & -.984 & .615 & 2.559 & 1 & .110 & .374 \\
\hline -Homemaker & -.443 & .221 & 4.036 & 1 & .045 & .642 \\
\hline -Student & -.717 & .229 & 9.759 & 1 & .002 & .488 \\
\hline -Not working & .955 & .291 & 10.758 & 1 & .001 & 2.600 \\
\hline Education level & & & 14.683 & 4 & .005 & \\
\hline -Some secondary & .054 & .362 & .022 & 1 & .882 & 1.055 \\
\hline -Secondary degree & .189 & .351 & .289 & 1 & .591 & 1.208 \\
\hline -Post secondary & -.366 & .361 & 1.030 & 1 & .310 & .693 \\
\hline -Bachelor's degree or higher & .265 & .425 & .388 & 1 & .533 & 1.303 \\
\hline \multicolumn{7}{|l|}{ Perceptual factors } \\
\hline Opportunity & .694 & .130 & 28.582 & 1 & .000 & 2.001 \\
\hline of failure & -.249 & .138 & 3.280 & 1 & .070 & .779 \\
\hline Confidence in one's skill & .753 & .127 & 34.978 & 1 & .000 & 2.123 \\
\hline Constant & -.009 & .463 & .000 & 1 & .985 & .991 \\
\hline
\end{tabular}

in developing countries like India, in which very few studies have been undertaken to understand what the venture creation phenomenon is?

Entrepreneurial intention has been considered as the best predictor of entrepreneurial activity (Krueger et al. 2000). This study is a preliminary step in understanding factors that affect entrepreneurial intention and consequently entrepreneurship. To our knowledge, no previous study has examined the relationship between various factors and entreprenruial propensity in Indian context using GEM data.

We have analyzed the influence of different cognitive perceptions and demographic factors on theintention to start a new business. For this purpose, we used Adult Population Survey, 2012 of India, which comprises a large sample of 2700 interviews. Logistic regression was used for the statistical analysis. This technique is appropriate for analyzing the effect of certain independent variables on the dichotomous dependent variable.

The analysis of demographic factors suggests that females, homemaker, and students are less likely to become entrepreneurs while part-time and not-working individuals are two times more likely to start their own businesses than those who are working full time. Besides the demographic factors, all the perceptual factors have a significant influence on entrepreneurial intention. The findings suggest that individuals who see good opportunities, do not feel fear of failure, they perceive that they have knowledge and skills and therefore, are likely to become entrepreneurs. 


\section{Limitations and suggestions for future research}

Of course, this study has several research limitations. First, related to the data provided by GEM consortium, the items related to cognitive aspects are few in number. Secondly, the nature of data prevents us more accurate statistical techniques such as structural equation modeling that may show mutual interaction among the variables. Finally, models based on cognitive approach were actually derived from European and American countries. Indians may not fully share the same frame of reference as their western counterparts regarding definitions of cognitive constructs and thought patterns.

Future research should investigate these variables with the addition of some other variables like, role model, public media attention, family background,etc. Another scope for future researchers is that these variables can be tested with industry specific entrepreneurial start up behavior and comparison of these industry specific studies may provide abetter understanding.

Moreover, it would be very interesting to compare these results with other countries in details that will provide help in taking lessons from other nations. To achieve this objective, countries could be grouped into three stages of economic development as defined by the WEF (World Economic Forum): factor-driven, efficiency-driven and innovation-driven. Cross-cultural studies may provide a better understanding of the phenomena.

Competing interests

The authors declare that they have no competing interests.

Authors' contributions

Both authors read and approved the final manuscript.

\section{Publisher's Note}

Springer Nature remains neutral with regard to jurisdictional claims in published maps and institutional affiliations.

Author details

${ }^{1}$ Department of Commerce, Aligarh Muslim University, Aligarh, India. ${ }^{2}$ Department of Commerce, Aligarh, Muslim University, Aligarh, India.

Received: 9 February 2017 Accepted: 2 June 2017

Published online: 17 June 2017

\section{References}

Ács, Z. J., Szerb, L., \& Autio, E. (2011). Global entrepreneurship and development index 2011 (Vol. 400). Cheltenham, UK Northampton MA, US: Edward Elgar.

Ajzen, I. (1991). The theory of planned behavior. Organizational Behavior and Human Decision, 50, 179-211.

Arafat, M. Y., \& Saleem, I. (2017). Determinants of entrepreneurial startups in India: A study using GEM data. In S. Misra, S. Shukla, \& G. Batthini (Eds.), Twelfth biennial conference on Entrepreneurship.Paper presented at twelfth biennial conference on entrepreneurship, entrepreneurship development Institute of India, Ahmedabad 22-24 February (656665). Delhi: Bookwell.

Arenius, P., \& Minniti, M. (2005). Perceptual variables and nascent entrepreneurship. Small Business Economics, 24(3), $233-247$.

Bandura, A. (1977). Self-efficacy: Toward a unifying theory of behavioral change. Psychological Review, 84(2), 191.

Bandura, A. (1982). Self- efficacy mechanism in human agency. American Psychologist, 37, 122-147.

Baron, R. A. (2004). The cognitive perspective: A valuable tool for answering entrepreneurship's basic "why" questions. Journal of Business Venturing, 19(2), 221-239.

Bosma, N. (2013). The global entrepreneurship monitor (GEM) and its impact on entrepreneurship research. Foundations and Trends ${ }^{\oplus}$ in Entrepreneurship, 9(2), 143-248.

Cacciotti, G., \& Hayton, J. C. (2015). Fear and Entrepreneurship : A review and research agenda *. International Journal of Management Reviews, 17, 165-190.

Ekore, J.O. and Okekeocha, O.C. (2012). Fear of entrepreneurship among university graduates: a psychological analysis. International Journal of Management, 29, pp. 515-524.

Fernández, J., Liñán, F., \& Santos, F. J. (2009). Cognitive aspects of potential entrepreneurs in Southern and Northern Europe: An analysis using GEM-data. Revista de economía mundial, 23, 151-178.

Frederick, H., \& Monsen, E. (2011). New Zealand's perfect storm of entrepreneurship and economic development. Small Business Economics, 37(2), 187-204. 
Greene, W. H. (2002). Econometric analysis (5th ed.). New York: Prentice Hall.

Honjo, Y. (2015). Why are entrepreneurship levels so low in Japan? Japan and the World Economy, 36, 88-101.

Kim, G. (2008). Entrepreneurship and self-employment: The state-of-the-art and directions for future research. New England Journal of Entrepreneurship, 11(1), 39.

Krueger, N. F. (2003). The cognitive psychology of entrepreneurship. In Z. J. Acs \& D. B. Audretsch (Eds.), Handbook of entrepreneurship research: An interdisciplinary survey and introduction(pp. 105-140). London: Kluwer.

Krueger, N. F., \& Carsrud, A. L. (1993). Entrepreneurial intentions: applying the theory of planned behavior. Entrepreneurship and Regional Development, 5(4), 315-330.

Krueger, N. F., Reilly, M. D., \& Carsrud, A. L. (2000). Competing models of entrepreneurial intentions. Journal of Business Venturing, 15(5), 411-432.

Langowitz, N., \& Minniti, M. (2007). The entrepreneurial propensity of women. Entrepreneurship Theory and Practice, 31(3), 341-364.

Lerner, J. (2010a). The future of public efforts to boost entrepreneurship and venture capital. Small Business Economics, $35(3), 255-264$

Lerner, J. (2010b). The future of public efforts to boost entrepreneurship and venture capital. Small Business Economics, $35(3), 255-264$.

Li, Y. (2011). Emotions and new venture judgment in China. Asia Pacific Journal of Management, 28(2), 277-298.

Liñán, F., \& Chen, Y. (2009). Development and cross-cultural application of a specific instrument to measure entrepreneurial intentions. Entrepreneurship Theory and Practice, 33(3), 593-617.

Liñán, F., Santos, F. J., \& Fernández, J. (2011). The influence of perceptions on potential entrepreneurs. International Entrepreneurship and Management Journal, 7(3), 373-390 http://doi.org/10.1007/s11365-011-0199-7.

Lortie, J., \& Castogiovanni, G. (2015). The theory of planned behavior in entrepreneurship research: What we know and future directions. International Entrepreneurship and Management Journal, 11(4), 935-957 http://doi.org/10.1007/ s11365-015-0358-3.

McMullen, J. S., \& Shepherd, D. A. (2006). Entrepreneurial action and the role of uncertainty in the theory ofthe entrepreneur. Academy of Management Review, 31(1), 132-152.

Mitchell, R. K., Busenitz, L., Lant, T., McDougall, P. P., Morse, E. A., \& Smith, J. B. (2002). Toward a theory of entrepreneurial cognition: Rethinking the people side of entrepreneurship research. Entrepreneurship Theory and Practice, 27(2), 93-104.

Noguera, M., Alvarez, C.., \& Urbano, D. (2013). Socio-cultural factors and female entrepreneurship. International Entrepreneurship and Management Journal, 9(2), 183-197.

Patzelt, H., \& Shepherd, D. A. (2011). Negative emotions of an entrepreneurial career: self-employment and regulatory coping behaviors. Journal of Business Venturing, 26, 226-238.

Ramos-Rodríguez, A. R., Medina-Garrido, J. A., \& Ruiz-Navarro, J. (2012). Determinants of hotels and restaurants entrepreneurship: A study using GEM data. International Journal of Hospitality Management, 31(2), 579-587.

Reynolds, P., Bosma, N., Autio, E., Hunt, S., De Bono, N., Servais, l., et al. (2005). Global entrepreneurship monitor: Data collection design and implementation 1998-2003. Small Business Economics, 24(3), 205-231.

Shane, S., Locke, E. A., \& Collins, C. J. (2003). Entrepreneurial motivation. Human Resource ManagementReview, 13(2), $257-279$.

Shane, S., \& Venkataraman, S. (2000). The promise of entrepreneurship as a field of research. Academy of Management Review, 25(1), 217-226.

Shapero, A. (1975). The displaced, uncomfortable entrepreneur. Psychology Today 9(6):83-88.

Shapero, A., \& Sokol, L. (1982). The social dimensions of entrepreneurship. Encyclopedia of Entrepreneurship, 72-90.

Tsai, K.-H., Chang, H.-C., \& Peng, C.-Y. (2016). Refining the linkage between perceived capability and entrepreneurial intention: Roles of perceived opportunity, fear of failure, and gender. International Entrepreneurship and Management Journal, 12(4), 1127-1145.

Van Praag, C. M., \& Versloot, P. H. (2007). What is the value of entrepreneurship? A review of recent research. Small Business Economics, 29(4), 351-382.

Welpe, I.M., Spörrle, M., Grichnik, D., Michl, T. and Audretsch, D.B. (2012). Emotions and opportunities: the interplay of opportunity evaluation, fear, joy, and anger as antecedent of entrepreneurial exploitation. Entrepreneurship Theory and Practice, 36, pp. 69-96.

Wennekers, S., \& Thurik, R. (1999). Linking entrepreneurship and economic growth. Small Business Economics, 13(1), $27-$ 56 http://doi.org/10.1023/A:1008063200484

Wennekers, S., Van Wennekers, A., Thurik, R., \& Reynolds, P. (2005). Nascent entrepreneurship and the level of economic development. Small Business Economics, 24(3), 293-309.

Zamberi Ahmad, S., Roland Xavier, S., \& Rahim Abu Bakar, A. (2014). Examining entrepreneurial intention through cognitive approach using Malaysia GEM data. Journal of Organizational Change Management, 27(3), 449-464. 